\title{
Assessment of Inclined Plate Planter for Line Sowing of Black Gram
}

\author{
Narendra H. Tayade* and Birbal Sahu \\ Farm Machinery and Power Engineering, Krishi Vigyan Kendra Kanker, India \\ *Corresponding author
}

\begin{abstract}
A B S T R A C T
The field investigation entitled assessment of inclined plate planter for line sowing of black gram [Vigna mungo (L.) Hepper] was carried out during kharif season 2019-20 on farmers field at Krishi Vigyan Kendra Kanker (CG) The experiment was conducted on an area of 5 ha by the active participation of farmers. The results indicated that the higher yield of black was obtained in the improved practices and per-cent change in yield was increased by 19.07 per cent as compared to farmers practices. The technological gap, extension gap and technology index were observed during the experiment and found satisfactory. This improved technology also gave higher gross return, net return with higher benefit-cost ratio than farmers' practices i.e. broad casting method. The productivity achieved under demonstration over farmer's practices created awareness and motivated the other farmers to adopt improved technology for blackgram cultivation.
\end{abstract}

Keywords

Black gram, Inclined plate

planter, Field capacity,

Technology index

Article Info

Accepted:

04 March 2020

Available Online:

10 April 2020

\section{Introduction}

Black gram (Vigna mungo L.) is originated in India where it has been cultivated from ancient times and is one of the most highly priced pulses in India. Being a legume, it enriches soil $\mathrm{N}$ content and has relatively a short (90-120 days) life span. Although it has been introduced to other tropical areas mainly by Indian immigrants about $70 \%$ of the world's Black gram still comes from India. Black Gram is a perfect combination of all nutrients which include 20 to $25 \%$ of proteins,
40 to $47 \%$ of starch along with ash, fats, carbohydrates and essential vitamins. It is boiled and eaten directly or used after splitting into dhal. It is extensively used in various culinary preparations and recommended for diabetes. The green pods are eaten as a vegetable which is highly nutritious. The hulls or the outer covering of gram and straw are used as a cattle feed. Plant growth and development of black gram are greatly influenced by various environ-mental factors such as temperature, light, water and nutrient availability (Rajam, 1997). Under 
abiotic stress conditions, where variations of above factors affect plant growth and development adversely resulting in a dramatic reduction of the crop yield.

In uttar bastar kanker district, black gram is the main pulse crop of kharif season and farmers sowing mainly by local practice i.e. broadcasting method because they emphasis only food grain (rice crop). Keeping this point in view the main objective of the study was to assess the performance of inclined plate planter for line sowing of black gram to create awareness as well as to increase yield of black gram in the district.

\section{Materials and Methods}

The study was done at Krishi Vigyan Kendra, Kanker, Chhattisgarh during Kharif Season 2019-20 in the farmers' fields. Field evaluation of TD inclined plate planter for sowing of black gram in 5 ha area were carried out in different villages of kanker district. Used Inclined plate planter having nine rows for sowing black gram with adjusting row spacing was $30 \mathrm{~cm}$. It was also calibrated in laboratory before use on farmers field for proper seed rate .The sowing was done in month of july with seed rate of $25 \mathrm{~kg}$ $\mathrm{ha}^{-1}$. Optimum plant population was maintained in the trails The organic fertilizers were applied as per improved practices as basal dose. Hand weeding within lines was done at 30-35 days after sowing (DAS). The crop was harvested at perfect maturity. Technology gap, extension gap and technology index were calculated as suggested by Samui et al., (2000) as given below.

Technology gap = Potential yield Demonstration yield

Extension gap $=$ Demonstration yield Farmers' yield
Technology index (\%) = Technology gap/Potential yield x 100

\section{Results and Discussion}

Field capacity of inclined plate planter was recorded as $0.40 \mathrm{ha} / \mathrm{h}$ with change in yield was found increased by 19.07 per cent i.e. The average yield of black gram $(924 \mathrm{~kg} / \mathrm{ha})$ was much higher by using this improved technology than average yield of farmers' practice i.e. $776 \mathrm{~kg} / \mathrm{ha}$ (Table 1).

Technology gap: The technology gap between the demonstration yield and potential yield was $276 \mathrm{~kg} / \mathrm{ha}$ for black gram.

Extension gap: The extension gap of 148 $\mathrm{kg} / \mathrm{ha}$ was recorded. This emphasized the need to educate the farmers through various means for the adoption of improved agricultural machineries and implements for increasing production (Table 1). This finding is in accordance with the observation of Hiremath and Nagaraju (2010).

The technology index: The technology index was found to be 23 shows the feasibility of the evolved technology at the farmer's fields. The lower the value of technology index more is the feasibility of the technology.

Economic return: The cultivation of black gram under improved technologies gave higher net return of Rs 21036/ha as compared to farmers' practices i.e. Rs 14110. The benefit-cost ratio of green gram under improved technologies was 2.32 as compared to 1.83 under farmers' practices. This may be due to higher yield obtained using inclined plate planter for line sowing of black gram compared to local check (farmer's practice). With the adoption of improved technology recorded higher gross returns (Rs $36960 \mathrm{ha}^{-1}$ ) as compared to local practice (Rs $31040 \mathrm{ha}^{-1}$ ) (Table 2) 
Table.1 Yield, technology gap, extension gap and technology index of black gram

Parameter

Crop

Variety

Area (ha)

Number of farmers

Yield (kg/ha)

Potential yield

Yield under improved technologies

Yield under local farmers' practices

Technology gap (kg/ha)

Extension gap $(\mathrm{kg} / \mathrm{ha})$

Technology index $(\%)$
Observation

Black gram

Indira Urd Pratham

5.00

09

1200

924

776

276

148

23

Table.2 Economics of improved technologies and local farmer's practices

Parameter

Gross return (Rs/ha)

Cost of cultivation (Rs/ha)

Net return (Rs/ha)

$\mathrm{B}: \mathrm{C}$
Improved technologies

36960

15924

21036

2.32
Local farmer's practices

31040

16930

14110

1.83

Plate.1 Sowing of black gram by using inclined plate planter

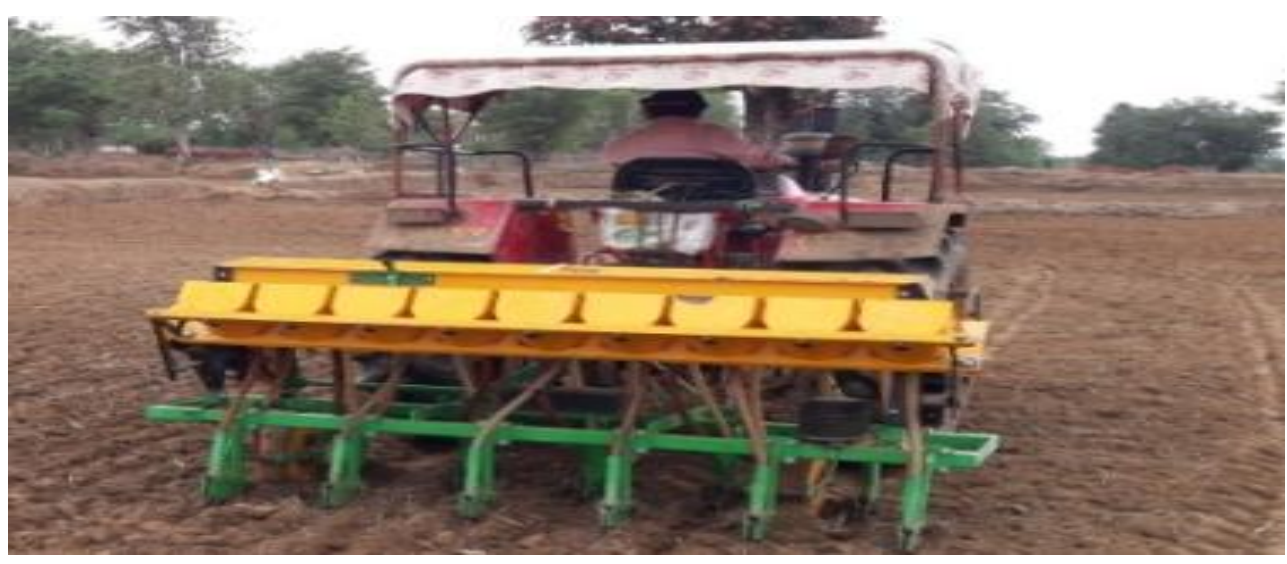


Plate.2 Black gram sown in line using inclined plate planter

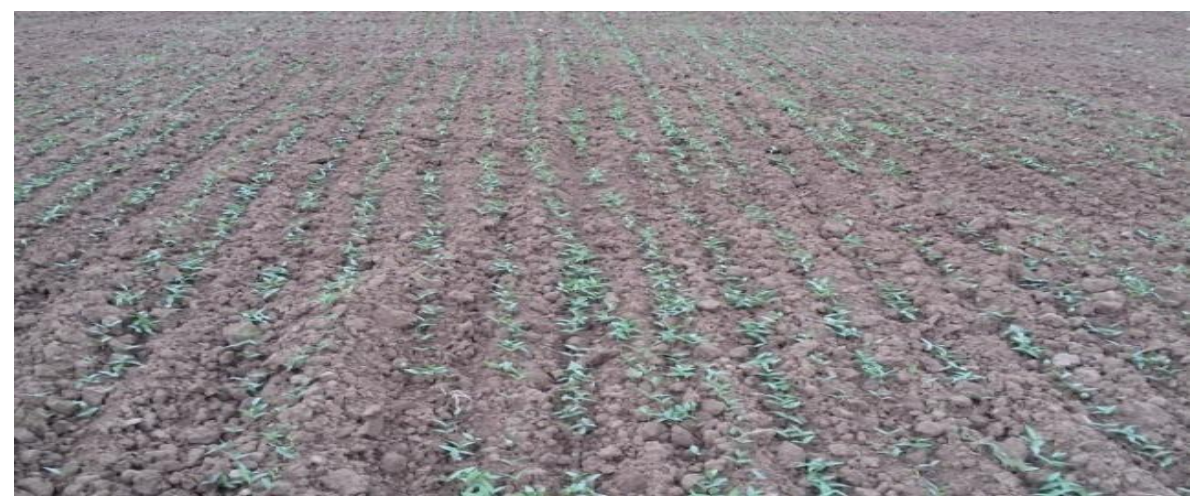

Reasons for low yield of black gram at farmers' fields: Lack of popularization of inclined plate planter/seed cum fertilizer drill for line sowing of black gram was found to be the main reason for low yield of green gram at farmers' fields. Also the farmers did not follow the optimum sowing time due to nonavailability of quality seed. In addition to it the farmers had been sowing seed using broadcast method due to which the plant population sometimes was 2-3 times more than the recommended one. However inclined plate planter helped in sowing the seeds in rows (Plate 2).

Conclusion: By using inclined plate planer grain yield was increased over the local check. The extension gap and technology gap was found to be $148 \mathrm{~kg} / \mathrm{ha}$ and $276 \mathrm{~kg} / \mathrm{ha}$ respectively. .As found in the results the B-C ratio (2.32) was also sufficiently high. The productivity achieved by using improved technology i.e. inclined plate planter over farmer's practices created awareness and motivated the other farmers to adopt this technology for black gram cultivation.

\section{References}

Hiremath SM and Nagaraju MV 2010. Evaluation of on-farm frontline demonstrations on the yield of chilli.
Karnataka Journal of Agricultural Sciences 23(2): 341-342.

Kiresur VR, Ramanna Rao SV and Hedge DM 2001. Improved technologies in oilseeds production- an assessment of their economic potentials in India. Agricultural Economics Research Review 14(2): 95-108.

Mukherjee N 2003. Participatory learning and action. Concept Publishing Company, New Delhi, India, pp 6365.

P.B. Jadhav, D.R. Kamble, K.T. Jadhav AND D.L. Gadpale. Performance of black gram [Vigna mungo (L.) Hepper] varieties to different sowing dates. Adv. Res. J. Crop Improv. Hind Agricultural Research and Training Institute; 5(2) Dec., 2014 :166-171

Poonia TC and Pithia MS 2011. Impact of frontline demonstrations of chickpea in Gujarat. Legume Research 34(4): 304307.

Reddy AA 2010. Regional disparities in food habits and nutritional intake in Andhra Pradesh, India. Regional and Sectoral Economic Studies 10(2): 125-134.

Samui SK, Maitra S, Roy DK, Mondal AK and Saha D 2000. Evaluation on frontline demonstration on groundnut (Arachis hypogea L). Journal of Indian Society of Coastal Agricultural Research 18: 180-183. 


\section{How to cite this article:}

Narendra H. Tayade and Birbal Sahu. 2020. Assessment of Inclined Plate Planter for Line Sowing of Black Gram. Int.J.Curr.Microbiol.App.Sci. 9(04): 43-47.

doi: https://doi.org/10.20546/ijcmas.2020.904.007 